\title{
LA REGULACIÓ \\ DE LA NAVEGACIÓ COMERCIAL PER MAR \\ EN TEMPS DE GUERRA. \\ L'ORDINACIÓ DE PERE III DE 1356
}

\author{
Hug Palou i MiQuel \\ Arxiu Municipal d'Arenys de Mar \\ (Barcelona)
}

\begin{abstract}
SUMARI
1. Introducció.- 2. Abast i limitacions de la prerrogativa reial per a dictar ordinacions marítimes d'abast general.- 3. Els precedents immediatament anteriors.- 4. L’Ordinació de 1356.- Apèndix documental.
\end{abstract}

\section{INTRODUCCIÓ}

Els períodes d'enfrontament bèl lic representen sempre una distorsió en l'exercici lliure del comerç en general i del marítim en particular. No obstant això, la navegació comercial, tot i que amb riscos, perills afegits, prohibicions $\mathrm{i}$ els consegüents perjudicis econòmics i socials, no deixà de practicar-se.

Era del tot habitual, almenys en l'Edat Mitjana, en temps de conflicte armat estès, però sobretot concentrat en el mar, ordenar el retorn de mercaders, patrons i embarcacions en viatge comercial, com també posar límits temporals a aquests viatges $\mathrm{i} / \mathrm{o}$ físics a les destinacions, o més senzillament prohibicions generals a la navegació. La raó fonamental solia ésser la preparació de l'armada - sempre mancada d'embarcacions grosses, majoritàriament galeres-, de l'estol que havia d'enfrontar-se a l'enemic en

"Anuario de listudios Medievales". 29 (1999) 
batalla, per la qual cosa fins que aquella no estava enllestida, o bé s'havia posat en marxa la seva organització, calia saber amb què es podia comptar; també per a la defensa de la costa en casos de prevenció o de necessitat. Altrament, era una manera d'evitar marques i les seves sempre incòmodes conseqüències, i embargaments per part de l'enemic. Amb independència dels estols, la pràctica del cors en aquests períodes constituïa el principal element de perill per a les embarcacions no militars.

Però això no era motiu perquè les relacions comercials per mar quedessin interrompudes del tot, en ocasions ni tan sols amb qui s'havia declarat la guerra encara que fos per un mitjà indirecte. En tot cas, guiatges, llicències, permisos, en ocasions excepcionals, quan s'oficialitzaven, ho feien possible. De tota manera, ja que les notícies no circulaven amb la rapidesa a què avui estem acostumats, hi ha circumstàncies en què patrons $\mathrm{i}$ mercaders podien veure embargades mercaderies i immobilitzat el vaixell perquè hi havia desconeixement de si s'estava en guerra, si l'enemic havia canviat, si hi havia treva, si aquesta havia acabat o bé s'havia allargat uns mesos, circumstàncies que podien portar a perillosos malentesos.

És en tot aquest àmbit d'inseguretat on les ordinacions reials que es manen publicar en temps de guerra adquireixen el seu just valor: l'ordenació de les activitats nàutico-comercials en el període teòricament excepcional de l'enfrontament armat real o latent ${ }^{1}$. I això és així fins al punt que, en tots els casos que conec, l'ordenació de la navegació comercial es produeix en temps de guerra, més enllà d'allò que contenen usos, costums i altres textos aplegats o no al Llibre del Consolat de Mar. Per tant, aquesta mena d'ordinacions són una perllongació de l'organització de la mateixa guerra, i la seva vigència estarà condicionada pel conflicte que la motiva, i es fixarà una durada determinada: fins que el conflicte acabés, fins que una nova ordinació la derogués, o bé fins que al rei li semblés de fer-la durar.

Al llarg del text aniran sorgint les implicacions de caràcter polític, social $\mathrm{i}$ econòmic que intervenen, com a condicionants, en el dictat,

\footnotetext{
'Vull remarcar que em refereixo a ordinacions reials o bé, com exposaré al seu moment. a ordinacions sancionades pel rei a proposta de municipalitats com la de Barcelona. En queden excloses les ordinacions específicament municipals que, fïns i tot en temps insegurs, és probable que no tractin directament aspectes relatius a defensa $i$ armament. Vegeu per exemple l'ordinació dels consellers i prohoms de Barcelona de 2 de juliol de 1343, que centra la seva atenció en la relació que s'ha d'establir entre mercader i patró per a nòlits que, carregats en el port de Barcelona, viatgin en embarcacions que es dirigeixin al Mediterrani Oriental, Ferran Valls I TAVerner, Consolat de Mar, III, Barcelona, 1933, pp. 13-16.
} 
l'aplicació i l'esmena d'aquestes ordinacions, matisant-les, limitant-les. Però he volgut fixar-me més en el vessant jurídic que intervé en l'origen i durant la vigència de les ordinacions, perquè és on troben suport alguns d'aquests condicionants.

La guerra entre Aragó i Gènova en temps del regnat de Pere III, que en diferents períodes d'enfrontament directe s'estén al llarg de gairebé tot el seu regnat, concretament a partir de l'any 1351 més enllà dels conflictes heretats, va provocar la publicació d'almenys quatre ordinacions navals considerades com a tals al Principat de Catalunya: dues per a la regulació de la navegació comercial (1354 i 1356), una per a l'organització de l'armada reial (1354) i una per a l'armament d'embarcacions per a la pràctica del cors (1356). De totes elles interessa, fonamentalment, l'ordinació per a la navegació comercial de 1356 , fins ara inèdita.

\section{ABAST I LIMITACIONS DE LA PRERROGATIVA REIAL PER A DICTAR ORDINACIONS MARÍTIMES D'ABAST GENERAL}

Entre les prerrogatives reials que el sobirà podia concedir en virtut de privilegi o gràcia especial, hi havia les que corresponien a la possessió del mar adjacent al territori ${ }^{2}$, és a dir, i sense correspondre's exactament amb els mateixos termes, el que avui en diem mar o aigües jurisdiccionals. Aquesta prerrogativa, que és reial quan escriu Andreu Bosch, anava lligada al domini de les Potestats durant l'Alta Edat Mitjana als territoris que esdevindran Principat de Catalunya ${ }^{3}$. I la veiem reflectida en diferents

\footnotetext{
${ }^{2}$ Andreu Bosch, Summari, index o epitome dels admirables y nobilissims títols de honor de Catalunya, Rosselló y Cerdanya, Perpinyà, 1628, p. 297.

${ }^{3}$ Això permetia, per exemple, que la potestat barcelonina, el comte Ramon Berenguer III, atorgués a la Seu de Barcelona, el 9 de juliol de 1130, la desena part de totes les lleudes $\mathrm{i}$ usatges que cobrava de les naus que arribaven, salpaven o simplement transitaven pel mar de Barcelona, amb l'única condició que la Seu no infeudés aquella concessió, vegeu Maria PARDO, Mensa episcopal de Barcelona (878-1299), Barcelona, 1994, doc. 21. Altres potestats podien fer el mateix en l'àmbit del seu domini, com ho feia el comte Ponç II Hug d'Empúries en definir al monestir de Santa Maria de Roses totes les lleudes que cobrava sobre tota mena d'embarcacions, «tam magnarum quam maximarum quam minimarum quam eciam maiorum que postmodum nominari possint", excepte l'usatge del peix i del corall, entre el cap de Creus i la Muga. Aquesta donació és confirmada pel comte Ponç III Hug en data de 26 de febrer de 1184 , fent esment de tota mena d'embarcacions, tant grosses com petites, que carreguessin o descarreguessin entre el cap de Creus i la Muga, lleuda que consistia en una peça amonedada
} 
Usatges que pervenen de constitucions de Pau i Treva, alhora que els seus continguts són refermats per diverses Constitucions de Catalunya.

Segons l'Usatge 60, el Príncep de Barcelona posava sota el seu especial guiatge, protecció i defensa totes aquelles embarcacions que, navegant des del cap de Creus fins al port de Salou, tinguessin la seva destinació en el de Barcelona o haguessin sortit del seu port ${ }^{4}$. Estenent el concepte, i seguint l'Usatge 62, totes les vies de comunicació, tant terrestres com marítimes, eren de la Potestat i, per a la seva defensa, havien d'estar permanentment en pau i treva ${ }^{5}$. Encara, Pere II, seguint la mateixa línia, reforça el contingut d'aquests Usatges amb el capítol 25 de la Cort de Barcelona de 1283, afegint-hi l'element econòmic: tothom podrà anar $\mathrm{i}$ tornar lliurement per mar o per terra per qualsevol camí, a qualsevol port, amb mercaderies o sense, sempre que fossin satisfets els vectigals, lleudes i peatges dels llocs acostumats, així com allò que corresponia a les prerrogatives reials ${ }^{6}$.

Es fa difícil determinar quina extensió podia tenir aquest mar territorial. L'Usatge 61 establia la pau i treva en el territori del pla de Barcelona amb una determinada perllongació dins la mar: dotze llegües a comptar, sembla, des de Collserola-Vallvidrera ${ }^{7}$. No ens ha de sorprendre que dotze llegües sigui la distància aproximada des del Tibidabo a l'horitzó, és a dir, la distància a partir de la qual començaria a ser visible un vaixell

"per cada càrrega carregada o descarregada dins d'aquells límits, vegeu Josep M. MARQUÈs, El cartoral de Santa Maria de Roses (segles X-XIII), Barcelona, 1986, docs. 3 i 5 respectivament.

${ }^{4}$ Usatge 60 , Omnes quippe naves, remeto a l'edició a cura d'en Joan BASTARDAS, Usatges de Barcelona. El codi de mitjan segle XII, Barcelona, 1984, pp. 92-93.

${ }^{5}$ Usatge 62, Camini et strate, BASTARDAS, Usatges, pp. 94-95. Sobre les referències d'aquest Usatge en les actes de diverses corts generals, vegeu Guillem M. de BroCÀ, Historia del Derecho de Cataluña especialmente del civil, I, Barcelona, 1985, p. 150, n. 16.

${ }^{6}$ En un sentit semblant s'expressa el rei Alfons II a la Cort de Montzó de 1289, capítol de Cort núm. 8, mentre Jaume II, a la Cort de Barcelona de 1299, capítol 15, hi introdueix l'element personal en excloure de la llibertat de moviments els pagesos de remença, vegeu Constitucions $i$ altres drets de Catalunya, Constitucions, Barcelona 1704, p. 291. En realitat, el pagament d'una quantitat en diner lligada al gaudi de la pau i treva del comte ja es veu de molt abans, com per exemple en el tractat de navegació entre el comte Ramon Berenguer III i els genovesos de l'any 1127, vegeu Josep BALARI, Orígenes históricos de Cataluña, Barcelona, 1899 , p. 658.

${ }^{7}$ Usatge 61, Item statuerunt, BASTARDAS, Usatges, pp. 92-95. El 23 de gener de 1320, Jaume II confirma la jurisdicció en mer i mixt imperi dins d'aquests mateixos límits, exposats d'altra manera, a favor de la ciutat de Barcelona, document on les dotze llegües semblen comptar-se des d'un altre punt, vegeu Brocà, Historia del Derecho, I, pp. 279-280, nots. 2 i 3 , i $294-295$, n. 2. 
des de la muntanya barcelonina i aquesta des d'una embarcacióo ${ }^{8}$. En el caràcter d'aquesta distància, tot $i$ tenir un vessant clar de control econòmic de la navegació des de terra ferma - les regulacions d'algunes lleudes de mar que obligaven a navegar a la vista de la costa per evitar el frau en són un clar exemple - , hi ha també el vessant defensiu, com veuren al tractar de l'Usatge Princeps Namque, igual que a darreries del segle XVIII i durant part del segle XIX, quan els límits dels mars jurisdiccionals de sobirania nacional venien determinats per la distància que abastava l'artilleria costanera, tres milles ${ }^{10}$.

És important tenir en compte els límits del mar territorial perquè és on més intensament s'intenvindrà per tal de regular la navegació comercial en temps de guerra $i$ no únicament per mitjà d'ordinacions ${ }^{11}$. No obstant això, les ordinacions, quan fixen distàncies concretes, ho fan en límits molt més propers a la costa $i$, en ocasions, concretant-se en determinades àrees geogràfiques en relació al conflicte vigent ${ }^{12}$.

${ }^{8} \mathrm{He}$ usat l'equivalència de la llegua antiga catalana que esmenten Claudi ALSINA, Gaspar Feliu, Lluís MARQUET, Pesos, mides i mesures dels Països Catalans, Barcelona, 1990, p. 168 , en comparació amb els càlculs que aporta Joan VERNET, La navegación en la Alta Edad Media, "Settimane di studi del Centro Italiano di Studi sull'Alto Medioevo", XXV, I (1977), pp. 323388.

${ }^{9}$ Vegeu l'exemple de la lleuda de Cotlliure i les mesures que Jaume I va prendre el 1266 per evitar el frau a Antoni RIERA, La lezda de Colliure bajo la administración mallorquina. I: la reforma de aranceles de finales del siglo XIII (1299?), "Acta Historica et Archaeologica Medievalia", 1 (1980), pp. 91-125.

${ }^{10} \mathrm{Per}$ a un concepte aparentment més concret com és el de platja contingut en el privilegi de consolat de mar de Barcelona, es va haver de dictaminar què s'hi havia d'entendre i fixar els límits que abastava. Aquests límits, dins dels quals eren d'aplicació el Capítols de Llotja, s'estenien dins la mar, encara que no es determina fins on; dins de la ciutat eren llocs coneguts, $i$ fora d'ella quinze destres terra endins des de l'aigua, amb exclusió de zones de població i de terres de conreu, vegeu Germà COLON, Arcadi GARCIA, Llibre del Consolat de Mar, III.2, Barcelona, 1984, doc. 12, de 14 de març de 1390; document inclòs en els comentaris a l'Usatge 61 , Item statuerunt, de Jaume MARQUILLES, Comentaria super usaticis Barchinone, Barcelona, 1557, fols. 166 v. $-167 \mathrm{r}$.

"Cal deixar de banda, en la discussió d'aquests límits marítims, aquells que hom pot trobar en documents de transmissió de propietats immobiliàries en els quals es fa esment del mar d'Espanya, ofins a trobar Mallorca, conceptes que prenen un caire fronterer.

'2És l'exemple de la ordinació de 1331 en la qual, amb caràcter general, totes les embarcacions petites, fins a 1.000 quintars, podran navegar per la costa compresa entre Pals $\mathrm{i}$ Cotlliure sense allunyar-se més de cinc milles i sempre que portin la dotació estipulada de gent d'armes; pel que fa a les embarcacions de menys de 300 quintars, el límit es fixa en tres milles, vegeu Josep M. MADURELL, Ordenanzas marítimas de 1331 y 1333, "Anuario de Historia del Derecho Español», (extret de 1961), pp. 611-628. 
Les ordinacions, com a normes de bon govern que eren, sense constituir de fet una norma general, sinó particular o especial relatives a una matèria determinada, amb la finalitat d'establir el mètode, ordre i concert que l'havia de regir, era disposada sempre per una autoritat superior la qual, en relació al seu rang, donava la mesura de la seva obligatorietat. Ho explica amb força claredat, altra vegada, Andreu Bosch: «la forma de ser los estatuts y ordinacions és segons resulta del poder de aquell qui las fa, o per privilegis, o altrament, uns de una manera, altres de altra, tots los quals estan obligat seguir la forma del poder tenen, altrament no lligan ni valen com se ha dit. De manera que la forma, forsa y valor és tant quant és lo privilegi y poder, e.s necessari sien publicades, altrament no lligan $»^{13}$.

Aquestes paraules d'A. Bosch pressuposen, com en realitat era, que una autoritat superior a la que dictava l'ordinació podia limitar-ne l'articulat o bé deixar-la sense efecte. D'aquesta manera, per exemple, el rei actuava quan algunes ordinacions municipals anaven en contra de les seves prerrogatives. Però també el rei podia veure afectada una ordinació reial, una vegada feta pública, si contrafeia allò que privilegis prèviament atorgats permetien, o vulnerava jurisdiccions que no li corresponien, baronials per exemple, alhora que no podia anar en contra dels Usatges ni del que s'havia acordat en Cort General ${ }^{14}$, havent de procedir, en molts casos, a la modificació, matisació o derogació d'aquells continguts conflictius o contraris. Més enllà dels condicionants legals en el manament i l'aplicació de les ordinacions reials generals, el pes polític i econòmic, lligat a situacions de carestia de determinades municipalitats - Barcelona n'és l'exemple prototípic-, podia afectar també el compliment de les ordinacions. Tot plegat podia portar a situacions d'un veritable estira i arronsa entre les parts.

El rei, doncs, tenia facultat per a dictar ordinacions que afectessin tot allò relacionat amb les seves prerrogatives, però també ordinacions de cảràcter general que, legalment, tindrien la consideració de pragmàtiques d'acord amb la capacitat legislativa del monarca ${ }^{15}$. En aquest sentit, és clara

\footnotetext{
${ }^{13}$ BosCh, Summari, p. 530.

${ }^{14}$ Tomàs MIERES, Apparatus super constitutionibus curiarum generalium Cathaloniae, Barcelona, 1621, II, p. 513, c. 1, punt 46.

${ }^{15}$ MIERES, Apparatus, I, p. 24, c. 1, punt 2. En ocasions, pel bé general, i per a casos molt concrets, sovint a petició de tercers, el rei podia delegar part d'aquesta capacitat de fer ordinacions. Ho podem veure, però, per al tema que m'ocupa, en capítols acordats en
} 
la intencionalitat pel bé general de l'ordinació objecte d'aquest article, com és habitual en aquesta mena de disposicions, exposat amb tota claredat en la seva intitulació: "Ordinacio facta per dominum Regem super forma navigandi pro tuycione subditorum suorum ac indemnitate reipublice» ${ }^{16}$. Amb termes semblants s'expressa en documentació posterior a la publicació de l'ordinació $^{17}$.

A tot això encara s'hi afegeix un altre element a tenir en compte. Corresponia al rei declarar la guerra $\mathrm{i}$ acordar la $\mathrm{pau}^{18} \mathrm{o}$, en termes més genèrics, tenia el deure de procurar la pau, la justícia, i la defensa i bon estat dels regnes ${ }^{19}$. Així mateix tenia l'exclusiva potestat de convocar l'Usatge Princeps namque per a la defensa del territori del Principat en cas d'invasió ${ }^{20}$. La pregunta esdevé òbvia: en el concepte d'invasió del

Parlament, no en Cort General, amb el que això suposa de no obligatorietat en el seu compliment per a aquells que no hi haguessin assistit, tot $i$ el caràcter general del contingut dels capitols on fins i tot el rei s'hi pot veure explícitament obligat. Vegeu l'exemple dels capítols 87 i 98 del Parlament de Vilafranca del Penedès de 1353, amb assistència de síndics de ciutats i viles reials, en el marc de l'organització de l'estol contra els genovesos, a Manuel SÁNCHEZ, Pere ORTí, Corts, Parlaments i fiscalitat a Catalunya: els capínols del donatiu (1288-1384), Barcelona, 1997, doc. XII.

${ }^{16} \mathrm{El}$ seu caràcter general és refermat en el capítol introductori, en afectar, l'ordinació, tota mena d'embarcacions que volguessin sortir "de ports, plages o mar[í]times de la senyoria del dit senyor, ne de lochs de la senyora Reyna, ni dels Infants, ni de prelats, richs homens ne d'altres sotmeses del dit senyor dins la dita senyoria deçà ne dellà mar", Arxiu de la Corona d'Aragó (des d'ara ACA), C., reg. 1402, fols. 29 r.-32 r., vegeu l'apèndix documental.

${ }^{17}$ L'ordinació havia estat feta uper bon estament dels regnes e terres nostres sobre lo fet del navegar" o bé per a «bon stament dels habitadors e navegants dels regnes e terres nostres». Així s'expressa el rei en el document pel qual permetia que els consellers de la ciutat de Barcelona poguessin autoritzar moviments d'embarcacions comercials a la seva ciutat. sense anar en contra de les ordinacions, si bé aquella mesura hi introduïa una modificació en quant a qui corresponia donar aquelles llicències, vegeu Antoni de CAPMANY, Memorias históricas sobre la marina, comercio y artes de la antigua ciudad de Barcelona, II.1, Barcelona, 1962, doc. 177, de 18 de febrer de 1357.

${ }^{18}$ Acaci de RIPOLL, Regaliarum tractatus, Barcelona, 1644, c. 43, paràgrafs 78 i ss., citat per Víctor FERRO, El Dret Públic Català. Les institucions a Catalunya fins al Decret de Nova Planta, Vic, 1987, p. 38.

${ }^{19}$ Mieres, Apparatus, I, p. 96, c. 1, punt 1.

${ }^{20}$ Usatge 68, Princeps namque, BASTARdaS, Usalges, pp. 102-103. Vegeu els comentaris sobre la importància i el caràcter exclusiu d'aquest Usatge, i en ocasions motiu de discussió per si en determinats casos el Lloctinent General el podia convocar, a Jaume MARQUILLES, Comentaria super usaticis Barchinone, Barcelona, 1557, fols. 199 v.-204 r., i MIERES, Apparatus, I, p. 383, c. 2, punts 1 a 3. 
Principat, s'hi entenia el mar territorial? La resposta pot ser raonablement afirmativa. Es dóna el cas que, pocs mesos després de publicada l'ordinació objecte d'aquest estudi, estant el rei a Perpinyà per a la celebració de Cort General, hom planteja la qüestió de si, davant el dubte que un grup de deu galeres genoveses es poguessin presentar a costa gironina, s'havia de convocar el Princeps namque. Els juristes del consell del rei, entre els quals hi era present Guillem de Vallseca, varen resoldre que «iste usaticos haberet locum quocienscumque extraneae gentes de quibus esset verissimilie posie damnum inferre in aliqua parte Cathaloniae sive per terram sive per mare veniant more hostili... ${ }^{21}$. Això pressuposaria, però, un abast de mar territorial potencialment superior a qualsevol visualització de l'enemic des de terra, fins i tot més enllà del límit de l'horitzó ${ }^{22}$. Ara bé, aquí, el mar és esmentat com a via d'accés a Catalunya, més que no pas com a un mar territorial. No obstant això, si l'acció defensiva es desenvolupés en el mar a partir de la convocatòria del Princeps namque, s'hauria d'entendre que aquesta operació s'esdevindria en el mar territorial, sense límits previs.

\section{ELS PRECEDENTS IMMEDIATAMENT ANTERIORS}

Un repàs a les ordinacions conegudes que es manen publicar al llarg de la primera meitat del segle XIV per a regular el comerç i la navegació mercantil, donen la mesura de la seva relació amb els diferents conflictes armats del període. Em refereixo, és clar, a les ordinacions pròpiament dites $^{23}$, però també a les lletres reials amb manaments concrets que es

\footnotetext{
${ }^{21}$ Antiquiores Barchinonensium leges, quas vulgus usaticos appellat, Barcelona, 1544, fol. 124 r. També Joan de SocarRats. In tractatum Petri Alberti (...) de consuetudinibus Cathaloniae inter dominos et vasallos (...) commentaria (...). Barcelona, 1551, p. 372, i MARQuILLES, Comentaria, fols. $200 \mathrm{r}$.-v., nota XVII, es fan ressò d'aquesta resolució dels juristes per a la convocatòria del Princeps namque.

2'BROCÀ, Historia del Derecho, I, pp. 151-152, qualifica aquest Usatge d'originari alhora que li assenyala el precedent d'una llei del temps de Vamba continguda en el Liber ludiciorum: II. 9, tit. 2, Ilei 8 (Quid debeat observari, si scandalum infra fines Hispaniae exsurrexerit) d'l de novembre de 673 . En aquesta llei es fixa en cent milles la distància física a partir de la qual el rei podia manar la mobilització general per a la defensa de la terra davant el perill d'invasió, he utilitzat l'edició continguda a Los Códigos Españoles concordados y anotados, I. Madrid, 1872, pp. 68-69. Vegeu també el concepte de platja referit a l'anterior nota 10.

${ }^{23}$ La coneguda ordinació de 1333 no és, en realitat, tal cosa sinó un conveni signat entre el rei d’Aragó i el de Mallorca amb els termes de l'acció conjunta, defensiva i ofensiva. contra els genovesos. Els capítols que el componen tracten genèricament de temes que afecten la
} 
relacionen amb aquesta temàtica, sense oblidar els capítols de Cort, més que no pas els de Parlament, que poden marcar directrius sobre les ordinacions que caldrà fer. Això fa que deixi de banda aquella documentació que afecta aspectes de caire més militar, que no és el que aquí m'ocupa ${ }^{24}$.

La primera ordinació que m'interessa destacar és la de 15 d'octubre de $1331^{25}$. El text de l'ordinació parteix d'una proposta dels consellers $\mathrm{i}$ prohoms de la ciutat de Barcelona adreçada al rei «ad utilitatem et bonum omnium navigancium terre nostre et ad tuicionem et deffensionem eorum contra januenses et alios volentes aut cupientes invadere seu offendere a navigantes gentes terre nostre». La conjuntura política situa aquesta ordinació

composició i organització de l'armada com també la defensa de la costa. l'autorització del cors. la prohibició de comerciar amb productes susceptibles de ser utilitzats en la construcció d'embarcacions per part de l'enemic en les mars pròximes a Gènova, o les prohibicions de contacte comercial amb la Senyoria $i$ amb embarcacions d'aquella procedència, vegeu MADURELL, Ordenanzas maritimas, pp. 618-621.

${ }^{24}$ En primer lloc la conegudissima ordinació promulgada per Pere III el 5 de gener de 1354 . obra de Bernat de Cabrera, per a la disciplina i bon govern de les armades reials, vegeu Antoni de CAPMANY, Ordenanzas de las armadas navales de la corona de Aragón aprobadas por el Rey D. Pedro IV año MCCCLIV, Madrid, 1787, pp. 1-21. Segueix l'ordinació «sobre la manera dels armadors de la sua senyoria” per a armar embarcacions dedicades al cors, de 26 de febrer de 1356, ACA, C.. reg. 1403, fols. 6 r. -9 v., publicada per CAPMANY, Memorias históricas, II.1, doc. 171. Incloc també en aquesta exclusió els convenis que regulen les accions conjuntes a portar a terme entre el monarca i altres institucions de poder civil o directament amb particulars: en general es tracta de capítols acordats per a l'armament d'embarcacions dedicades al cors que servissin per a empaitar l'enemic o de manaments reials que s'hi refereixen directament, ibidem, doc. 162, de 28 d'agost de 1351; ibídem, doc. 164, de 28 de març de 1353; documents que en ocasions inclouen capítols que imposen límits i condicions a la navegació corsària, com ho veiem en els acords celebrats entre el consell reial a València i la ciutat i els seus armadors, ja iniciada la guerra amb Castella-Gènova, posant els límits físics de l'actuació de les dues galeres que s'armaran des de l'illa de Sardenya ençà a les parts d'Espanya (Castella la Vella, I'Estret. fins i tot Sevilla i Lisboa), alhora que hauran de seguir navegació de conserva, ibídem, doc. 184, de 6 de maig de 1359. Tampoc les ordinacions de caràcter econòmic $i$ els capítols acordats en Parlament que regulen les contribucions en diner que la pràctica de la navegació comercial haurà d'aportar per a ajudar en la guerra $i / o$ en la organització de l'armada. Serveixin d'exemples l'ordinació dels consellers de la ciutat de Barcelona, sancionada per Alfons III, per a contribuir en la organització d'una armada contra sarraïns, on es fixen taxes sobre diferents productes alimentaris i sobre els vaixells que arribin al port de Barcelona o que en surtin, d'acord amb el tipus d'embarcació i la seva capacitat de port que determinen, alhora, el seu possible radi d'acció comercial, ibidem, doc. 97, de 14 d'abril de 1315; o els capitols 29 a 32 acordats en el Parlament de Vilafranca, que aplegà síndics de ciutats $i$ viles reials entre els mesos de març $i$ abril de 1353, per a contribuir en el finançament d'una nova armada contra Gènova o, més genèricament, a l' 'ajuda en la guerra de Còrsega, de Cerdenya e dels jenoveses», vegeu SÁnchez; Ortí, Corts, Parlaments, doc. XII.

${ }^{25}$ ACA, C., reg. 537. fols. 54 v.-59 r., publicada per MADURELL, Ordenamzas marítimas, document II. L'ordinació és producte, en el seu redactat final, d'una ampliació, probablement mallorquina, d'un text presentat prèviament en data de 4 de juliol del mateix any, ACA, C., reg. 537. fols. 44 r. -50 r., ibidem, doc. I. 
en els anys de guerra declarada entre Aragó i Gènova (1331-1335), alhora que ho fa també en els de la croada pactada entre Alfons XI de Castella i Alfons III d'Aragó de 1329 en contra de Granada, que comptava amb el suport de Gènova. El tractat de pau signat el 1334 per Castella. Fes, Granada i Aragó posarà fi, momentàniament, a aquella situació bèl·lica ${ }^{26}$. Ens trobem encara en uns dels darrers episodis del conflicte conegut per «guerra de l'Estret».

L'ordinació prohibia de forma general la navegació entre Pals i Aigües Mortes, entre Mallorca i Menorca, i fins a arribar a Sardenya, aigües en què actuarien els genovesos, prohibició de la qual quedaven excloses les embarcacions que anessin armades segons determinava l'ordinació. Els homes i el material que havien de constituir l'armament variarà segons el tipus i grandària del vaixell que, alhora, servia per a determinar la llunyania respecte de la costa per on es podria navegar. Aquests límits podien ser imposats també segons el tipus de carregament transportat.

L'ordinació regula molt directament aquestes zones de navegació on s'afecta les embarcacions petites i mitjanes, des de barques de 300 quintars fins llenys de 2.500 quintars, i embarcacions a rem de 30 fins a, almenys, 80 rems. Per a les embarcacions a vela de major port no es prohibeixen zones concretes de navegació, però si que es delimiten radis d'acció comercial, alhora que es determina el nombre de gent d'armes, armament $i$ defenses amb què hauran d'anar dotades. Aquest era el cas de les coques, de dues i tres cobertes, per a les quals, des de 1.000 a 2.000 salmes de port, podrien navegar fins a Mallorca, Sevilla, Flandes i Cotlliure, mentre que les que fessin de 2.000 a 3.000 salmes podrien arribar a Sicília, Tunis i tota la Berberia en el benentès, però, que, venint de Sicília o de Nàpols haurien de seguir navegació de conserva un mínim de dues embarcacions, fins a arribar a Mallorca. Finalment, a les naus de tres cobertes i de més de 3.500 salmes, els era permès navegar sense límits, $i$ havien d'anar de conserva amb una altra nau pel cas que naveguessin cap al Mediterrani oriental; l'únic tipus d'embarcació facultada per a fer-ho.

\footnotetext{
${ }^{26}$ Manuel SÁNCHEZ, Las relaciones de la Corona de Aragón con los países musulmanes en la época de Pedro el Ceremonioso, «Pere el Cerimoniós i la seva època», Barcelona, 1989, pp. 77-97, M. Dolores LÓPEZ PÉREZ, La Corona de Aragón y el Magreb en el siglo XIV (13311410), Barcelona, 1995, pp. 664-665. Aquell mateix any el rei havia concedit a la ciutat de Barcelona capacitat per a posar capita de guerra dins de les embarcacions barcelonines que naveguessin mentre aquell conflicte continués, vegeu CAPMANY. Memorias históricas, II.1, doc. 136 .
} 
Els consellers de Barcelona, adjunt a la proposta d'ordinació, demanaven al rei que li plagués escriure al de Mallorca perquè fes una ordinació de tipus semblant, de manera que tothom quedés afectat. El resultat sembla ser la inclusió de nou capítols de règim intern sobre el que s'havia de seguir sobre els mariners dins de l'embarcació. Aquests mateixos nou capítols, ampliats, seguint el mateix ordre que en l'ordinació de 1331, encapçalen l'ordinació de Pere III de 1340.

Els «Capítols del rei en Pere sobre los fets e actes marítims» de data 22 de novembre de $1340^{27}$, s'emmarquen en la guerra contra els merínides que, ara si, constituiria el darrer episodi de la "guerra de l'Estret». L'any 1339. el Tractat de Madrid celebrat entre Aragó i Castella convidava el rei Pere III a col-laborar amb el seu potencial marítim amb el sobirà castellà. Després de la campanya d'estiu de 1339 en què Pere III va enviar un petit nombre d'embarcacions a la zona, no hi va destinar una altra flota fins tot just iniciada la tardor de 1340. Així, la conjuntura de l'ordinació se situa una vegada produïda la victòria musulmana de Tarifa (abril de 1340) i una vegada, també, aconseguida la victòria castellano-portuguesa d'El Salado (octubre de 1340) que, malgrat tot, no havia allunyat la por a un intent d'invasió de la Península ${ }^{28}$.

El contingut de l'ordinació és divers i general, com en el mateix preàmbul s'indica, $i$ reflexiona sobre el que es pot fer respecte a les coses futures quan aquestes ens són conegudes per l'experiència del passat, raó per la qual hom opina que, en realitat, el rei Pere no va fer altra cosa que aplegar en un sol text normes disperses, com són els nou capítols darrers de l'ordinació de 1331. Altrament el rei s'adreça, en l'ordinació, als seus oficials als regnes de Sardenya i Còrsega, València, Catalunya, i al comtat i ciutat de Barcelona. La seva redacció no pressuposa, ni hi fa esment concret, que la publicació estigués motivada per una situació bèl-lica concreta. Tot això hauria col-laborat a fer que el text de l'ordinació s'afegís a la compilació barcelonina del Llibre del Consolat de Mar - completant-la

\footnotetext{
${ }^{27}$ Valls I Taverner, Consolat, II, 1931, p. 7, diu treure l'original de l'ACA, C., reg. 871 , fols. $115 \mathrm{r}$. i ss. La transcripció és continguda a les pp. 11-34.

${ }^{28}$ LÓPEZ PÉREZ, La Corona de Aragón, pp. 69-89.
} 
en alguns aspectes- $i$, de retop, a la valenciana $i$ a la mallorquina cap als anys $1348-1349^{29}$.

L'ordinació regulava qüestions d'ordre intern, també econòmiques, en embarcacions destinades al comerç; dels barquers al servei de les embarcacions comercials; participació i drets dels perçoners; seguretat de les mercaderies transportades i com es reparteixen les responsabilitats; actituds en cas de naufragi o perill d'ell; actituds i mesures a prendre en cas d'atac d'embarcacions enemigues o corsàries; acords patró-mercaders. També inclou capítols de temes molt més específics, com per exemple la prohibició de treure fusta de roure i d'alzina per part de qui no fos de la jurisdicció del rei, o la regulació de la pràctica d'algun art de pesca per tal de no entorpir l'accés al port de Barcelona.

Cal fer notar que, encara que dins de la dotació de l'embarcació es fa esment reiterat de la presència de ballesters, ho és als capítols manllevats de l'ordinació de 1331 - que són els que castiguen amb penes de mort als contrafactors-, més als mpl0 a mp14 i al mp39. La mateixa procedència té el capítol dedicat a l'enumeració de l'armament que mariner o ballester havien d'embarcar ${ }^{30}$, no res excepcional, d'altra banda, si s'inclouen mesures per a prendre davant d'atacs de corsaris o la topada amb embarcacions militars hostils, situació massa habitual com per no fer-ho així ${ }^{31}$. Tampoc s'imposen límits a la navegació, ni s'obliga a la navegació de conserva, i l'únic esment de destinacions, Ultramar, és en capítols procedents de l'ordinació de 1331.

En tot cas es tracta d'una ordinació que es va publicar en un moment determinat dels afers exteriors de Pere III i que, amb una sèrie d'elements armamentístico-defensius, es va incorporar al Llibre del Consolat de Mar.

\footnotetext{
${ }^{29}$ COLON; GaRCIA, Llibre, III.1, Barcelona, 1984, pp. 164-165, i 270-271; són imprescindibles els treballs d'Aquilino IGLESIA, Libro do Consulado da Mar, "Anuario de Historia del Derecho Español», (extret de 1986), pp. 219-439, i La formación de los libros de Consulado de Mar, «Initium», 2 (1997), pp. 1-372.

${ }^{30}$ Capítol mp8: «Item, que tot meriner o balester de nau o leny o altre vaxel qui prenga loguer de nau sia tengut de metre armes, so és a saber bones cuyrasses, gornera, capel de ferro et spaa e coltel e bones dues balestes e I croch e CC passadors o viratons, e que deja aqueles armes emprar tota vagada que per son major se sia request per deffenció de la nau o leny" de l'edició de Colon; Garcia, Llibre, II, Barcelona, 1982, p. 269.

${ }^{31} \mathrm{Ja}$ ho veiem d'aquesta manera al text que regula l'activitat comercial i portuària a la ciutat de Barcelona l'any 1258, conegut com "Ordinacions de la ribera marítima de Barcelona", capítols V, VII i XII, vegeu Valls I TaVerner, Consolat, II, 1931, pp. 119-136.
} 
El darrer precedent de què vull fer esment, és la immediatament anterior ordinació de 4 de març de $1354^{32}$.

A partir de 1351 s'enceta una nova guerra amb Gènova. La guspira, però, es remunta a uns mesos abans, quan esclata la revolta dels Doria a Sardenya ${ }^{33}$ i els genovesos es posen al costat dels insurgents $i$ reben l'oferiment de la possessió de l'Alguer ${ }^{34}$. El 16 de gener de 1351 Pere III s'alia amb Venècia, l'enemic natural dels genovesos en el control dels mercats d'Orient, i acorden que el seu enfrontament amb Gènova s'esdevindria en el mar. Pocs mesos després, el 19 d'abril, Pere III feia públic el memoràndum de declaració de guerra ${ }^{35}$.

La durada de la guerra amb Gènova serà llarga i, tot i períodes de relativa tranquil litat paral $\cdot$ lels als esdeveniments sards, no arribarà a la fi, i encara momentàniament, fins a l'any 1378. El desenvolupament de la guerra tindrà els seus moments més representatius coincidint amb aquells que mouen la necessitat d'organitzar una armada i quan es conegui, s'analitzi i es difongui el resultat de la seva acció bèl-lica.

Quan es publica l'ordinació de 1354, tot just feia dos mesos que s'havia publicat la famosa ordinació de Bernat de Cabrera per a l'organització de l'armada reial, després de la victòria aconseguida l'estiu anterior (17 d'agost de 1353), en aigües de l'Alguer, contra l'armada genovesa.

La preparació d'aquest estol ja es projectava pel novembre de $1352^{36}$. Les primeres conseqüències que cal destacar, prèvies a l'ordinació, són dues lletres reials on es disposen normes per a la navegació comercial. El dia 3 de gener de 1353, donat el perill per a la navegació que l'estat de guerra amb Gènova suposava, Pere III s'adreçava al Batlle General de Catalunya perquè fes publicar per tots els mars de Catalunya la prohibi-ció, aplicable a tots els seus súbdits, de navegar, ja fos per mars properes o

\footnotetext{
169.

${ }^{32}$ ACA, C., reg. 1400, fols. 79 v.-82 r., vegeu CAPMANY, Memorias Históricas, II. 1, doc.

${ }^{33} \mathrm{~A}$ la Cort de Perpinyà de 1350-1351 ja s’hi acorda una imposició general sobre el vi, els cereals i els draps de llana per tal de contribuir en "lo fet del Alguer", vegeu SÁnchez; OrTi, Corts, Parlaments, doc. X, de 22 de novembre de 1350.

${ }^{34} J$ Jerónimo ZURITA, Anales de la Corona de Aragón, IV, Zaragoza, 1978, pp. 188-190.

${ }^{35}$ Crónica del rey de Aragón D. Pedro IV el Ceremonioso, edició a cura d'Antoni de BofarULl, Barcelona, 1850, pp. 294-295, ZURITA, Anales, IV, pp. 204-207.

${ }^{36}$ Bofarull, Crónica, pp. 302-304, Zurita, Anales, IV, pp. 231-236. Amb la finalitat de reunir diners per a la formació d'aquest estol, el rei convoca Parlament a Vilafranca del Penedès, celebrat entre març i abril de 1353, Sánchez; OrTí, Corts, Parlaments, doc. XII.
} 
llunyanes i, amb independència del tipus d'embarcació (nau, coca, lleny o barca), posar, portar, transportar o carregar cap mena de mercaderia. S'entenien excloses de la prohibició: vitualles, carbó, pedres de molí, terrissa, espart, palma i fusta, productes que sí que podien embarcar-se en els vaixells esmentats sempre que naveguessin per mars properes. Així mateix, qui volgués navegar o mercadejar per mar, per on li semblés, ho podria fer lliurement anant amb galera o galeres armades amb gent de la terra. Qualsevol llicència donada amb anterioritat quedava en suspens mentre la guerra durés.

Mes i mig després, el 28 de febrer, atesa la notícia que Gènova estava armant deu galeres per entrar en acció aquell mateix mes, i en previsió del mal que podrien fer a qui navegués, el rei feia publicar per tots els llocs de mar, fins i tot a Barcelona, que cap dels seus súbdits, amb independència de la seva condició, navegués per cap mar, excepte amb embarcacions de la terra i transportant vitualles, eixàrcies $i$ altres coses, sots pena de mort al contrafaent i l'embargament del vaixell amb el seu carregament. Així mateix s'imposava un límit temporal a la navegació: durant el mes d'abril s'havia d'estar de retorn als llocs dels quals haguessin sortit.

Davant d'aquestes mesures, els consellers i prohoms de la ciutat de Barcelona varen fer saber al rei que s'anava en contra de privilegis, usos $i$ costums de la ciutat, fent esment concret dels enunciats dels capítols 84 i 85 del Recognoverunt proceres ${ }^{37}$ i del capítol 7 de la Cort de Barcelona de 1283 sobre l'eliminació de l'impost de la gabella de la sal en tot Catalunya $^{38}$. El rei, vist el contingut de les seves lletres $\mathrm{i}$ dels privilegis, usos $\mathrm{i}$ costums al·legats, refermà la validesa de les seves prohibicions ${ }^{39}$.

\footnotetext{
${ }^{37}$ Són, respectivament, del tenor següent: «Item, concedimus capitulum quod naves, lembi, barchae et quelibet alia vasa civium Barchinone possint navigare, intrare, exire, carricare et discarricare, vendere, emere et stare in quibuscumque locis voluerint, per portus et alia loca Cathaloniae, ipsis tamen solventibus iura et lezdas antiquitus consuetas"; "Item, concedimus capitulum quod quilibet habitator Barchinonae possit navigare et portare quascumque merces voluerit, et quocumque voluerit, excepto grano, farina, ferro, armis, lenyam, fil de exarcia et pegunta, et exceptis locis inimicorum nostrorum cum quibus habeamus guerram, quam vobis significaverimus", els traiem de l'edició continguda a la compilació Constitucions $i$ altres drets de Catalunya, Pragmàtiques, Barcelona, 1704, p. 47.

${ }^{38}$ Constitucions $i$ altres drets de Catalunya, Constitucions, p. 299.

${ }^{39}$ Els tres documents referits, en un de sol, és a CAPMANY, Memorias Históricas, II.1, doc. 169, extret de l'Arxiu Històric Municipal de Barcelona (des d'ara AHCB), Llibre Verd, II, fols. 341 v.-343 v. Uns anys més tard, el rei va fer publicar una prohibició que impedia l'extracció de tota mena de productes tèxtils obrats o per obrar del Principat, ja fos per terra o per mar.
} 
La victòria de Bernat de Cabrera no va impedir un nou brot en les revoltes del jutge d'Arborea, davant de la qual el rei decidí intervenir-hi personalment, i es traslladà a Sardenya amb un nou estol i posant setge a l'Alguer ${ }^{40}$. És en aquesta conjuntura, una vegada decidida la formació de l'armada i abans que l'estol salpés del port de Roses el juny d'aquell any, en què es publica l'ordinació de $1354^{41}$.

L'ordinació manava, de forma general, que cap embarcació de comerç sortís de cap port ni de cap platja de Catalunya, inclosa la de Barcelona, sense la corresponent llicència. La llicència, atorgada pel Consell Reial a Barcelona o, en substitució seva, pel Batlle General de Catalunya, el seu lloctinent o bé qui s'hagués diputat per a poder-les atorgar, permetia la navegació en determinades condicions, alhora que el text distingeix entre zones de més i de menys perill on poder-ho fer, àdhuc sense llicència, de la manera següent:

- les embarcacions de comerç («navilis o vaixells grans o petits»), podien navegar, amb llicència, des del cap de Leucata fins a Cervera, i només seguint la costa. No seria necessària la llicència per a navegar, amb aquesta mena d'embarcacions i seguint la costa, entre Tortosa i Roses.

-les mercaderies susceptibles de tenir un valor econòmic elevat, únicament podrien ser transportades en llenys, barques i llaguts, tots ells armats i navegant prop de la costa.

-només les galeres $i$ les naus, armades $i$ amb llicència, tindrien possibilitat de navegar cap a les illes de Mallorca, Eivissa i Sardenya, o més enllà. En aquests casos es podria transportar tota mena de mercaderia, amb

Els consellers de Barcelona varen replicar al rei que aquella prohibició anava en contra del capítol 85 del Recognoverunt proceres, davant de la qual cosa el rei va revocar l'aplicació de la prohibició a la ciutat de Barcelona, AHMB, Llibre Verd, II, fols. 189 v.-190 r., ibídem, doc. 181 de 5 de gener de 1358 .

${ }^{40}$ Bofarull, Crónica, pp. 310-318, Zurita, Anales, IV, pp. 237-265. Els síndics del braç reial reunits al Parlament de Barcelona el 2 de gener de 1354 , atorgaren al rei donatiu in subsidium expensarum per nos fiendarum in guerra vigente inter nos et ianuenses, nostros publicos inimicos, pro Sardinie et Corsice regno et in exequtione quam fieri ordinavimus in Sardinia contra nonnullos nobis ibidem rebellantes...", SÁnCHEZ; OrTí, Corts, Parlaments, doc. XIII, p. 133.

${ }^{41}$ Una vegada el rei a Sardenya, les dificultats de l'exèrcit que assetjava l'Alguer varen portar a la convocatòria d'un nou Parlament del braç reial a Barcelona «pro succurrendo ipsi domino regi de gentibus, armis, victualibus et aliis ei necessariis ad complendum et perfficiendum exequtionem iustitie quam idem dominus rex personaliter facit contra nonnullos sibi rebelles in regno Sardinie», SÁNCHEZ; ORTí, Corts, Parlaments, doc. XIV, p. 143, de 23 d'agost de 1354. 
independència del seu valor, excepte coses vedades. Els capítols 4 a 7 de l'ordinació descriuen la manera en què haurien d'anar armades i amarinades aquestes embarcacions, si bé tan sols es fixa en naus a partir de 2 cobertes i més de 1.500 salmes de port, procedint a una gradació, en relació a la seva grandària, del nombre de mariners, ballesters i servicials que havien de proveir-les.

- les embarcacions estrangeres, sempre que no fossin de terres dels enemics del rei, podrien venir, anar, vendre, comprar i treure les seves mercaderies, excepte coses vedades, assegurant, però, que tot allò que traguessin no ho portarien a terra d'enemics del rei.

- cap súbdit del rei no podria sortir del Principat en vaixells estrangers, ni essent pelegrins, de la mateixa manera que tampoc no podrien treure mercaderies pròpies. Malgrat aquesta prohibició, se'ls permetia treure mercaderies, excepte coses vedades, amb embarcacions estrangeres que es dirigissin més enllà de l'estret de Gibraltar. Així mateix, si algun súbdit del rei feia importar per mitjà d'embarcació estrangera cereals o altra vitualla, podria treure mercaderies fins a assolir el mateix valor d'allò importat, excepte coses vedades, també en embarcació estrangera.

-en els casos que al rei li semblés necessari, es donaria llicència a embarcacions petites $\mathrm{i}$ armades (lleny, barca, llagut) per a missions de missatgeria i espionatge, prohibint que cap d'aquests vaixells pogués treure mercaderies o gent de la terra més enllà del nombre d'homes necessaris per al funcionament i armament de les embarcacions.

L'ordinació, després de refermar que cap súbdit del rei no podria navegar si no era amb una embarcació de la terra, dedica els darrers capítols a qüestions més generals com la taxa de les llicències, el registre d'albarans, i l'aplicació de les penes que en cada cas es determinen - fins i tot la pena de mort- per aquells que contrafessin allò que és regulat per l'ordinació.

El darrer episodi d'aquest capítol és del març de 1355. El braç reial, reunit en Parlament a Lleida, atorgava un nou donatiu al rei per a la formació d'un estol de cinquanta vaixells que garantís el retorn, sa i estalvi, del rei des de l'illa de Sardenya, ja que hi havia l'amenaça que els genovesos estiguessin armant una flota de seixanta galeres per impedir-ho ${ }^{42}$. Entrat l'estiu es va saber que els pocs vaixells dels quals disposaven els genovesos es trobaven entrebancats al port de Trípoli. Alhora, els afers sards estaven

\footnotetext{
${ }^{42}$ SÁnCheZ; Ortí, Corts, Parlaments, doc. XV, de 17 i 18 de març de 1355.
} 
prenent un nou rumb. Calia modificar els termes del donatiu en la seva aplicació ja que aquell estol ja no era necessari, tant que, únicament varen acordar trametre al rei les cinc galeres que estaven armades i pagades ${ }^{43}$.

La pau signada entre venecians i genovesos, i la situació a Sardenya, va fer possible la pau de Sanluri entre el rei i el jutge d'Arborea l'11 de juliol de $1355^{44}$. S'encetava un parèntesi que no posava fi, però, ni momentàniament, al problema sard i genovès. No obstant això es tancava l'etapa dels grans enfrontaments navals entre aquests protagonistes, etapa que fins i tot s'encarrega de remarcar la Crònica del Cerimoniós deixant de parlar de la guerra i les revoltes de Sardenya per encetar un nou tema d'interès, la guerra amb Castella, al costat de la qual hi participarà Gènova ${ }^{45}$.

\section{L'ORDINACIÓ DE 1356}

La intencionalitat de l'autor de la Crònica, contràriament als seus interessos, no va evitar que se seguissin nous episodis d'aquell conflicte. Si la darrera Cort General, la de Perpinyà de 1350-1351, havia tractat de la guerra de Sardenya amb el complement de la Cort de Lleida de 1352, la següent Cort que se celebrarà, també a Perpinyà, convocada el 10 de maig de 1356 per iniciar-se mes i mig més tard, tindrà l'assoliment de la pạu àmb. Gènova com a tema central ${ }^{46}$.

El dia 20 de febrer el rei tramet una lletra als batlles generals de Catalunya, València, Mallorca i als governadors de Logudor i Càller adjuntant els capítols de la prohibició de fer transport comercial per mar, en previsió del perill i danys que els genovesos i altres enemics del rei podrien causar. L'ordinació s'havia de publicar el 15 de març següent ${ }^{47}$.

\footnotetext{
${ }^{43}$ SÁncheZ; Ortí, Corts, Parlaments, doc. XVI, de 13 i 14 de juliol de 1355.

${ }^{4}$ Zurita, Anales, IV, pp. 270-275.

${ }^{45}$ Bofarull, Crónica, pp. 319-321.

${ }^{46}$ Cortes de los antiguos reinos de Aragón y Valencia y Principado de Cataluña, I.2, Madrid, 1896, pp. 482-504, ibídem, XV, Madrid, 1911, pp. 148-151 i 408-434.

${ }^{47} \mathrm{ACA}, \mathrm{C}$, reg. 1402 , fols. 32 r.-v.
} 
Paral $\cdot$ lelament, una altra ordinació, aquesta per a fixar una normativa per a l'armament d'embarcacions dedicades al cors, es tramet a les ciutats de Barcelona, Perpinyà, Cotlliure, València, Mallorca i Càller ${ }^{48}$.

L'ordenació nàutico-comercial de 1356 , fins ara inèdita i que forma l'apèndix documental d'aquest article, introdueix interessants i notables modificacions respecte de l'ordinació de dos anys abans, la qual és específicament revocada i anul-lada per la nova publicació.

L'ordinació, que té per finalitat la regulació de la navegació comercial per mar en temps de la guerra amb Gènova, afegeix al seu objecte les revoltes de Sardenya i Còrsega. Per esquivar la prohibició general de la navegació, que afectava tota mena d'embarcacions que volguessin sortir de platges, ports i costes del Principat (no només de llocs reials, sinó també dels de la reina, infants reials, eclesiàstics, nobles laics, etc.), calia, a més de seguir el que regulava l'ordinació, i com era habitual, estar sempre en possessió de la corresponent llicència. La llicència havia de ser lliurada per escrit per aquell a qui el rei hagués diputat, tasca que requeia en el Batlle General de Catalunya o en el seu lloctinent. No seguir el que establia l'ordinació podia comportar la pena de mort per a l'infractor.

La navegació era ordenada de la manera següent:

- les embarcacions a rem i vela - fa esment concret i específic de galeres, galeres grosses ${ }^{49}$, i d'uixers amb funcions comercials-, podrien navegar per on volguessin, amb tota mena de mercaderies, excepte coses vedades, amb la condició d'haver d'anar amb un mínim de dos homes per

${ }^{48}$ ACA. C., reg. 1403, fols. 6 r.-9 v., CAPMANY, Memorias históricas, II.1, doc. 171. Aquesta ordinació, que fixa la seva atenció, com és obvi, en l'armament de galeres -únicament dedica dos capítols de la vintena que la forma a l'armament de naus-, venia a reordenar els convenis particulars que el rei establia amb l'armador per a la pràctica del cors, donava forma normativa a velles pragmàtiques del segle XIII, i completava, per a una necessitat concreta, els capitols d'armades i cors continguts al Llibre del Consolat de Mar, vegeu Colon; GARCIA, Llibre, II, pp. 211-261.

${ }^{49} \mathrm{La}$ galera era l'embarcació de tịpus militar típica: la seva elevada dotació en homes i la relativament reduïda capacitat de transport comercial impedien que pogués ser considerada una embarcació comercial a l'ús, amb una rendibilitat discutible, excepte pel tòpic de mitjà ideal per a transportar mercaderia de luxe, de poc pes, relatiu poc volum i alt preu. Aquest vessant militar $i$ circumstancialment comercial ta que en les ordinacions que estudiem sigui dificil trobar esment de les galeres, tot el contrari de quan les ordinacions són sobre la organització d'armades i del cors. A l'ordinació de 1331, per exemple, l'únic esment que es fa del tipus de vaixell galera és quan es fa referència de lleny's de més de 80 rems, que hi són assimilats. Tot i això, a partir de final del segle XIII, les galeres s'aniran fent més grosses, afavorint el vessant comercial, que podrà anar en detriment d'alguna de les seves virtuts com a embarcació militar, ja que esdevindrà més pesada i més lenta, vegeu Marco TANGHERONI, Commercio e navigazione nel Medioevo, Roma-Bari, 1996, pp. 196-202. 
rem i 20 sobresallents. No obstant això, recomana tres remers per banc que, tenint en compte que es refereix al mateix tipus de vaixell, imprimirien més velocitat a l'embarcació, i 30 sobresalients. Es regula que per a navegar per mar oberta calia anar de conserva amb una altra embarcacióo ${ }^{50}$; no era necessari si es navegava per la costa. En qualsevol de les maneres es prohibia fer-ho per les costes de Gènova, Còrsega i Sardenya.

-les naus, a partir de 2.000 salmes, també podrien navegar per on els semblés i amb tota mena de mercaderies, amb les mateixes prohibicions que les galeres. Per a obtenir la corresponent llicència les naus havien de portar un mínim de cent homes entre mariners, ballesters i servicials; per cada cent salmes de més de port la nau havia d'augmentar la seva dotació en cinc homes en la proporció d'un ballester i un servicial per cada tres mariners. A més d'això, la nau havia d'anar dotada de defenses passives $i$ d'armament. No s'obliga a la navegació de conserva.

-les embarcacions petites, tant cobertes com descobertes, (barques i llaguts de pesca), podien seguir pescant i navegant per la costa del Principat transportant solament vitualles, llenya, carbó, terrissa i espart.

- tots els altres tipus d'embarcacions havien de ser avarades en terra o entrades en ports ben defensats en el termini de quinze dies després de la publicació de l'ordinació. Per a aquells vaixells que en el moment de fer-se pública estiguessin navegant, el termini comptaria a partir que haguessin retornat si així ho volien, en el benentès que ho havien de fer sense mercaderia. La pena als contrafaents es fixa en l'embargament del vaixell.

-d'aquesta regulació en quedaven excloses les embarcacions estrangeres en els mateixos termes que en l'ordinació de 1354, prohibint, com aleshores, que gent de la terra sortís del Principat en aquestes embarcacions. No obstant això s'hi introdueix un matís. En aquella ordinació els súbdits del rei no podien treure mercaderies en vaixells estrangers llevat que anessin més enllà de l'estret de Gibraltar —com també es permet en aquesta-, o bé que abans haguessin importat vitualles. Ara, en canvi, es permetrà treure mercaderies en vaixells estrangers fins un valor de 25 sous barcelonesos el quintar.

\footnotetext{
${ }^{50} \mathrm{M}$. Teresa Ferrer I MALLol, La naregació de conserva a l'Edat Mitjana, "Anuario de Estudios Medievales", 24 (1994), pp. 453-464, troba a faltar en l'ordinació de 1356 la navegació de conserva, quan l'ordinació a què fa referència és la de l'armament de cors. Les ordinacions de cors, només ocasionalment, incloïen aquesta mena de precaució.
} 
-s'insisteix en continguts de l'anterior ordinació com la prohibició que ningú navegués amb embarcació que no fos de la terra, que es repeteix en dos capítols consecutius; que es pogués, si al rei li semblava, llicenciar embarcacions petites i armades per a fer missions de correu o espionatge; alhora que també es dediquen alguns capítols a la fixació de la taxa per a les llicències i a les seguretats pel compliment de l'ordinació. En aquest darrer aspecte s'afegeix, respecte de la de 1354, que en naus, galeres i uixers hi viatgessin dues persones diputades pel rei, obligades amb prestació de jurament i homenatge, per tal de controlar, dins de les embarcacions, el fidel compliment de l'ordinació.

-finalment, ja que aquells súbdits del rei que contrafessin allò que mana l'ordinació s'haurien d'enfrontar a la pena de mort, es permet que es poguessin emprendre accions corsàries contra aquells que naveguessin incomplint els capítols, establint el repartiment del guany segons si l'embarcació en què fossin trobats era dels dominis del rei o bé dels de la reina, prelats, nobles o d'altres.

El redactat de la nova ordinació és més dur que el de la de 1354. Pot ser degut al fet que, malgrat tot, no hi havia previsió d'armar cap estol per entrar en batalla ni per contenir, a mar obert, les embarcacions enemigues; per tant tampoc no havia un estol enemic i aquest es feia notar amb accions pròpiament corsàries, amb la inseguretat que això comportava. Més encara, Pere III acordà un tractat amb el rei de França, els termes del qual ja es presenten el 8 de gener de 1356, per aportar quinze galeres aparellades i amarinades, més un nombre d'homes a cavall, en el seu enfrontament amb el rei d'Anglaterra. A canvi, el rei de França, es comprometia donar al rei d'Aragó 24.000 florins d'or cada any per aguantar la guerra de Sardenya mentre durés el pacte que celebraven. Tampoc s'estava de lliurar galeres per necessitats de la ciutat de Barcelona ${ }^{51}$.

Aviat es començaran a introduir modificacions en l'articulat de l'ordinació. La primera que conec és de menys de dos mesos després de la

\footnotetext{
${ }^{51}$ ACA, C., reg. 557, fols. 199 r.-200 r., CAPMANy, Memorias históricas. II.1, doc. 173, de 17 d'abril de 1356. Mesos després el rei permet la devolució a la ciutat de Barcelona de les galeres amb què havia contribuït als estols armats contra Gènova, ibídem, doc. 176, de 13 de setembre de 1356. Entrat l'any següent, permetia als consellers de Barcelona treure galeres reials de la drassana de la ciutat, ja fos per a defensa. per a transport d'aliments com per a altres necessitats ciutadanes, amb la facultat de poder navegar lliurement d'acord amb l'ordinació vigent, AHCB, Llibre Verd, II, fols. 181 r. i 356 v.-357 r., ibídem, doc. 178, de 19 de febrer de 1357.
} 
publicació, moguda per probables queixes dels consellers i prohoms de la ciutat de Barcelona i/o Mallorca esperonats, possiblement, pels perjudicis econòmics i socials que l'aplicació de l'ordinació els causava. El rei permetrà que, tot $\mathrm{i}$ les prohibicions, pel bé públic de la ciutat de Barcelona i dels seus habitants, i pels de les Balears, es puguin transportar vitualles $i$ altra mena de mercaderies amb qualsevol tipus de vaixell, excepte forment, ordi i civada, que eren necessaris a Barcelona. Alhora autoritzarà que en embarcacions estrangeres hi puguin embarcar mercaderies per a qualsevol destinació, excepte en llocs d'enemics, de la qual cosa n'assabenta a tots els seus oficials tant de mar com de terra ${ }^{52}$.

L'estiu d'aquell any els genovesos varen atacar algun port del litoral català, com Lloret ${ }^{53}$, i en alguna ocasió les notícies informaven de grups de galeres genoveses que, amb la intenció de fer mal, s'atansaven a la costa del Principat. És en aquest moment en què els juristes del consell del rei resolen sobre supòsits d'aplicació de l'Usatge Princeps namque, del qual ja he parlat, alhora que el rei pren noves mesures que modifiquen l'ordinació. Primer endurint el seu articulat en permetre únicament la navegació per la costa i només per a aquelles embarcacions que l'ordinació autoritzava. Però, unes setmanes després, novament el perjudici econòmic que patia la ciutat de Barcelona, els seus habitants, va fer anul·lar l'aplicació de la prohibició en aquesta ciutat i deixar les coses com estaven abans, segons l'ordinació general $^{54}$.

El 30 de juny anterior havia començat la Cort de Perpinyà. El rei demanava a la Cort ajuda en la guerra contra Gènova i pels afers sards. Amb el record de la victòria naval de Bernat de Cabrera de prop de tres anys abans, la Cort aconsellava al rei l'assoliment d'una pau que li fos honorable, alhora que, «car los dits janoveses són gens caviloses e mestres», aconsellaven de prendre un seguit de mesures per a la defensa del Principat ${ }^{55}$.

\footnotetext{
${ }^{52}$ AHMB, Llibre Verd, II, fol. 354 v., CAPMANY, Memorias históricas, II.1, doc. 174, de 9 de maig de 1356.

${ }^{53}$ Josep M. PONS I GURI, La sentència sobre el castell de Lloret, "Annals de I'Institut d'Estudis Gironins», XXVI (1982-1983), pp. 87-108, reproduït a "Recull d'estudis d'Història jurídica Catalana", III, Barcelona, 1989, pp. 163-182.

${ }^{54} \mathrm{ACA}$, C., reg. 1403, fols. 56 v.-57 r., CAPMANY, Memorias históricas, 11.1, doc. 175 , de 6 d'agost de 1356 (16 de juliol); vegeu també CaPMANy. Ordenanzas. pp. 71-72.

${ }^{55}$ Els braços demanaven al rei que fes tornar les galeres deixades al rei de França: que no iniciés cap altra guerra sense que ho acordés la Cort; que no portés fora del regne gent d'armes que poguessin ser necessàries al Principat; que d'abril a setembre hi haguessin deu galeres
} 
Encara, un any després de redactada l'ordinació, el rei seguia essent receptor de queixes per part de la ciutat de Barcelona sobre els capítols d'aquella. Els dubtes i qüestions que es plantejaven en l'aplicació del seu articulat, quant a la condició i grandària dels vaixells, sobre allò que portaven i, també, sobre els negocis pels quals anaven o venien, va decidir Pere III a introduir un nou canvi. Des d'aleshores els consellers de Barcelona estaven facultats per a donar les llicències que fins aleshores corresponia lliurar al Batlle General de Catalunya, al seu lloctinent, o al Vicealmirall de Catalunya, però només per a allò que correspongués als habitants de Barcelona o bé als forans que volguessin arribar a la ciutat. Més tard el rei introduirà un matís: aquella facultat només la podrien exercir en defecte del Batlle General ${ }^{56}$.

\footnotetext{
defensant la costa del Principat: que volgués diputar persones amb poder suficient per a donar llicències de cors $i$ fer ordinacions; $i$ que no es procedís a l'alienació d'embarcacions aptes per a la guerra ni d'elements dels seus aparellaments, vegeu Cortes de los antiguos reinos, I.2, pp. 500-504.

${ }^{56}$ AHCB, Llibre Verd, II, fol. 356 v.. CaPMANY, Memorias históricas, II.1, doc. 177, de 18 de febrer de 1357, i AHCB, Llibre Verd. II, fol. 366 r., ibidem, doc. 180, de 16 d'agost
} de 1357 , respectivament. 


\section{APÈNDIX DOCUMENTAL}

1356, febrer, 26. Barcelona.

Ordinació per a la regulació de la navegació comercial feta i manada pel rei Pere III en el marc de la guerra amb Gènova i la revolta de Sardenya i Còrsega.

Arxiu de la Corona d'Aragó, Cancelleria, Registre 1402, fols. 29 r.-32 r.

Ordinacio facta per dominum Regem super forma navigandi pro tuycione subditorum suorum ac indemnitate reipublice.

I. Ordena, vol e mana lo senyor Rey, per rahó de la guerra que ha ab los Jenoveses e altres enamichs seus e per squivar que $\cdot$ Is seus sotmeses no prenguen dampnatge, que alcuns navilis o vexells grans o pochs de la sua senyoria no pusquen ne gossen partir de ports, plages o mar[i]times de la senyoria del dit senyor, ne de lochs de la senyora Reyna, ni dels Infants, ni de prelats, richs hòmens ne d'altres sotmeses del dit senyor dins la dita senyoria deçà ne dellà mar, sots pena de cors $\mathrm{e}$ d'aver, sinó en la forma següent. Ex provisione.

II. Declara emperò lo dit senyor, que tota galea o galeas grosses, uxer o uxers, armades o armats a .III. tires et ab .XXX. sobresalients e d'armes e d'altres furniments, o a tot lo menys a .II. tires et ab .LX. (sic) sobresellents, a coneguda del dit senyor Rey o de aquells qui per ell sobre açò seran deputats, pusquen navegar per portar vitualles e altres mercaderies per costeres o per golfos o la un se volran. Exceptat emperò que no gosen navegar en la costera de Jènova ne en lochs sotmeses a jenoveses o a lurs senyors, ne en lochs dels rebelles al senyor Rey en Cerdenya e en Còrcega. Declara emperò lo senyor Rey que, si alscuns uxers o galeas grossas armats e armades en la forma demontdita nevegaran per golf, que hajen anar .II. en conserve, emperò que per costeres puscha anar una galea sola armada e .I. uxer armat en la forma demontdita. Emperò que no gosen trer ne portar coses vedades. Ex provisione.

III. Item, declara lo dit senyor que tota nau o naus qui sien de port de.II. mil salmes $0<0\rangle$ de .Il. mil salmes ensús, pusquen naveger per portar vitualles c altres mercaderies per costers o per golfs o la un se volran, exceptat que no gosen 
nevegar en la costera de Jènova ne en lochs sotmeses a genoveses o a lurs senyors, ne en lochs dels rebells al senyor Rey en Sardenya et en Còrcega, axí emperò que no gosen treer ne portar coses vedades. E si la nau serà de port de .II. mil salmes haja e deja menar .C. persones tengudes de nau, ço és a saber .LX. mariners, .XX. ballesters e .XX. servicials, los quals hajen de XVI anys ensús e tots hajen compliment de lurs armes. E si la nau serà de port de més de .II. mil salmes, que meta e deja metre. $\mathrm{V}$. hòmens més avant per centenar de salmes que la dita nau més portarà axí mariners, ballesters com servicials al compte demontdit, e que la dita nau o naus sien encuyrades de popa a proha e ben encastellades e entoldades e enfaalçades e fornides d'armes e de tots altres forniments necessaris a la dita nau o naus a coneguda de aquells que $\cdot 1$ dit senyor sobre açò deputarà, los quals sien tenguts de fer sagrament e homenatge de haver-se sobre açò bé et leyalment. Ex provisione.

IIII. Vol emperò e ordona lo dit senyor, que alcuna de les dites galeas e naus e uxers per lo dit senyor licenciades et licenciats segons que dit és, no gosen partir sens licència e letra o albarà del dit senyor Rey o de aquelles persones qui per ell sobre açò seran deputats en aquells lochs dels quals aytals naus, galeas e uxers partiran, les quals persones a açò deputadores sien tengudes de fer sagrament et homenatge en poder dels officials majors dels lochs on seran deputades, que ells bé e lealment se hauran en los dits affers no mudant en res la forma damontdita. Ex provisione.

V. Vol encara e ordona lo dit senyor que, per mills servar la sua ordinació demontdita, que en cascuna de les dites naus, galeas et uxers licenciades et licenciats per lo dit senyor segons que dit és, sien deputats. II. bons hòmens de aquells qui iran en les dites naus, galeas e uxers, ab poder de les persones qui seran deputades per lo senyor Rey en los lochs dels quals aytals naus, galeas e uxers partiran, los quals sien tenguts de fer sagrament et homenatge en poder de les dites persones, de fer, tenir et observar ab acabament als patrons de les dites naus, galeas e uxers la dita ordinació segons que damont se conté. Ex provisione.

VI. Item, declara lo dit senyor, que totes barques e leuts de pescar, descubertes et descuberts, qui són acostumades et acostumats de navegar per costera et de pescar, puguen navegar et pescar per les costers de la senyoria del senyor Rey et de terres de sos sotmeses ab gran, vin et altres vitualles, lenya et carbó, obra de terra, et spart, no portant alscunes mercaderies altres ne navegant per golf. Ex provisione.

VII. Item, vol e mana lo dit senyor, que tots e sengles altres vexells e navilis de la senyoria del dit senyor et de terres de sos sotmeses, exceptats los demunt declarats, sien trets en terra e meses en ports defenents dins .XV. dies aprés que la present ordinació serà publicada, sots pena de perdre lo dit vexell. Emperò declara lo dit senyor que, si alscuns dels dits navilis no eren en temps que la present ordinació se publicarà en los lochs d'on serien, que aquells navilis haien spay de 
tornar a lurs lochs, si tornar hi volran, sens robes emperò o mercaderies. E que dins .XV. dies aprés que seran junts en lurs lochs sien trets en terra o mesos en ports deffenents, sots la dita pena. Emperò en açò no sien entesos los vexells qui en temps que la present ordinació se publicarà seran absents de la terra e senyoria del senyor Rey tro que sien junts en les terres e senyoria del dit senyor. E lavors sien tenguts de tenir et observar la dita ordinació sots la dita pena. Ex provisione.

VIII. Item, mana et ordona lo dit senyor que, en aquesta inibició, no sien enteses alscuns navilis o vexells qui sien de persones d'estranya nació, ans aquestes pusquen navegar, venir, star et tornar a lur voluntat, vendre et comprar et trer lurs mercaderies exceptades, emperò, coses vedades; et asseguren convinentment en poder de aquelles persones qui per lo senyor Rey sobre açò seran deputades, que açò que hic trauran no porten en la costera de Genoa ne en lochs sotmeses a genoveses, a lurs senyors ne en lochs de rebelles al senyor Rey en Serdenya et en Còrcega, ne encara no gossen traure ne levar alscunes robes o mercaderies dels sotmeses de la senyoria del dit senyor lo quintar de les quals no valla més de .XXV. solidos Barchinonenses, e que de-çò facen sagrament los dits strangers, e si eren trobats en lo contrari que fossen punits de la frau et perjuri a coneguda del senyor Rey o de aquells qui per lo dit senyor hi seran deputats. Ex provisione.

IX. Item, que tot patró stranger, ans que pertescha de la senyoria del senyor Rey, faça sagrament en poder de les persones qui sobre açò per lo senyor Rey seran deputades, que lo levarà, portarà ne navegarà homes de la senyoria del dit senyor dins ne fora la sua senyoria sens special licència del senyor Rey. Ex provisione.

$X$. Item, ordona e mana lo dit senyor, que si alscunes persones de la senyoria del dit senyor Rey carregaran o trauran alcunes robes o mercaderies oltra la valor de .XXV. solidos Barchinonenses lo quintar e aquelles carregarà en vexell o vexells qui no sien capitulats segons la forma demontdita, que perden les dites robes e mercaderies, e la persona o persones d'aquell o d'aquelles qui en los dits vexell o vexells iran stien a mercè del senyor Rey. Ex provisione.

XI. Item, mana et declara lo dit senyor, que los sotmeses del dit senyor Rey, no contrastant la dita inibició, puguen et puxen trer lurs mercaderies e robes de la senyoria del dit senyor Rey, exceptades coses vedades, ab navili et navilis de stranya nació qui sien de port de mil salmes o de més pus que asseguren que passen dreta via dellà l'estret de Gibraltar. Ex provisione.

XII. Item, mana et ordena lo dit senyor, que negun mercader, nauxer, mariner, ballester, servicial, palagrins ne nenguna altre persona de la senyoria del dit senyor Rey, no gos ne deja anar ne navegar sinó tantsolament ab navili dels sotmeses et de la senyoria del senyor Rey segons l'ordinació del dit senyor, et açò sots pena de cors et d'aver. Ex provisione.

XIII. < Item, mana et ordena lo dit senyor, que negú mercader, nauxer, mariner, ballister, servicial, palagrins ne nenguna altre persona de la senyoria del dit senyor Rey, no gos ne deja anar ne nevegar sinó tantsolament ab navili dels 
sotsmeses et de la senyoria del senyor Rey segons l'ordinació del dit senyor, et açò sots pena de cors e d'aver. Ex provisione. $>$

XIIII. Item, mana et ordena lo dit senyor que, en cas que a ell fos ben vist faedor, o aquells qui ell ho comanarà, d'enviar o licenciar alscuns lenys armats, barches armades o lauts per missatgeria o per pendra lengua, que en aytal cas se puixa fer, emperò que les dits lenys armats o barches armades e lauts armats no hi puixen trer cambi ni mercaderies ni altres robes, ne palagrins ni altres persones de la senyoria del dit senyor sinó tantsolament aytantes persones com fossen necessàries en armament dels dits lenys armats, barques armades o lauts armats si donchs no havien licentia del dit senyor o dels damuntdits. E si lo patró o patrons dels dits lenys o barchas o lauts eren atrobats en lo contrari, que sien encorreguts en pena de cors et de aver. Ex provisione.

$\mathrm{XV}$. Item, vol et ordona lo dit senyor, que $\cdot \mathrm{ls}$ scrivans qui seran deputats per los damuntdits a fer los alberans, les dites lịcències, no demanen ne reeben per quescun alberà, per gran que sia, sinó .IIII. diners, et .II. diners per alberà de resposta dellà on seran anats et no més avant, et que llls dits alberans sien registrats largament per lo qual registrar no prenguen res sinó segons que dit és, et alguns dels dits scrivans no presumesquen ne gosen pendre més avant ne donen algú empetxament als demuntdits per haver res més, sots pena de perdre lurs officis et de estar a mercè del senyor Rey. Ex provisione.

XVI. E si per ventura alcú o alcuns sia, que sien de la senyoria del dit senyor o de la terra de la senyora Reyna, dels Infants o prelats, richs hòmens o d'altres sotsmeses del senyor Rey, per lur folia fahien o venien contra los dits capítols o alcun d'aquells, sien encorreguts, sens tota mercè, en pena de cors et d'aver; et si eren atrobats en la mar ab vexells o navilis faents contra les ordinacions damuntdites, lo dit senyor, ab la present ordinació, dóna licència a tot cossari et altre sotsmès seu que pusquen pendre de fer los dits vexells e navilis ab tot ço qui en aquells serà atrobat. E si aytals vexells o navilis seran de la terra del senyor Rey, que la meytat dels dits vexells o navilis et de les coses qui en aquells seran atrobades sien del senyor Rey e l'altra meytat d'aquells qui los dits vexells o navilis hauran preses; e les persones sien preses e estiguen a merçè del senyor Rey. E si-ls dits vexells o navilis o robes e mercaderies qui en aquells serien atrobades seran de la terra de la senyora Reyna, dels Infants, de prelats, de richs hòmens e d'altres sotsmeses del senyor Rey, que la terça part dels dits vexells o navilis e robes $\mathrm{e}$ mercaderies qui en aquells seran atrobades sia del senyor Rey e la terça del senyor de la terra al qual seran los dits vexells e navilis e robes e mercaderies, e l'altre terça d'aquells qui $\cdot$ ls hauran presos; e les persones estien a merçè del senyor de qui seran. Declara emperò lo dit senyor que, si les robes o mercaderies qui seran atrobades en los vexells o navilis de la senyora Reyna, dels Infants, prelats, richs hòmens et d'altres sotsmeses de la senyoria del senyor Rey que, en aquest cas, la 
meytat de les dites robes et mercaderies sia del senyor Rey a l'altre d'aquells qui $\cdot$ ls hauran preses. Ex provisione.

XVII. Item, lo senyor Rey, ab tenor de la present inibició, revoca e anul-la totes altres inhibicions de navegar per ell o per sos officials fetes tro al jorn de la publicació de la present inhibició. Ex provisione.

XVIII. Item, mana lo dit senyor, fortment e espressa, a procuradors, governadors, batles, veguers, justícies e a tots altres officials del senyor Rey deçà et delà mar constituïts, que la sua ordinació demontdita e les coses contengudes en aquella tenguen e observen, e tenir e observar façen, segons tenor e continència de aquella. $\mathrm{E}$ algun dels dits officials no presumescha alcuna cosa tocar ne mudar en la dita ordinació ne fer o venir contra aquella, sots pena de perdre lurs officis sens tota merçè et de star a merçè del senyor Rey. Datum Barchinona XXVI dies de fabrer en l'any de la nativitat de nostre senyor M CCC LVI. Ex provisione.

Dominus Rex qui eam vidit et correxit mihi Ferrario de Magarola in suo plenissimo consilio.

\section{RÉSUMÉ}

Les ordonnances royales, qui régissaient la navigation commerciale maritime publiées en temps de guerre -exemple de l'activité commerciale dans ces periodes exceptionnelles en même temps qu'exemple de la suite de l'organisation propre à la guerreétaient soumises aussi bien dans leur dictée que dans leur accomplissement à une série de conditions. Ces conditions, en rapport aussi bien avec les prérrogatives royales qu'avec les droits et les besoins de ceux qui devront les accomplir, conduiront à des modificacions ét corrections constantes d'adéquation avec des implications politiques, sociales et économiques. L'Ordonnance de 1356, jusqu'à nos jours inédite, et sa documentation annexe en sont un échantillon.

\section{SUMMARY}

The royal ordinances that regulated the commercial sea navigation, published in war times, both example of the commercial activity during these exceptional periods and prolongation of the organisation of the war itself, were subject, both in its dictation and in its fulfilment, to a series of determining factors. These determining factors, related to the royal prerrogatives but also to the rights and the necessities of the ones to whom its fulfilments will be demanded, will lead to constant modifications and adaptation amendments with political, social and economical implications. The Ordinance of 1356, up to now unpublished, and its attached documentation are a proof of that. 